CIVICS EDUCATION AND SOCIAL SCIENSE JOURNAL(CESSJ)

Volume 2 Nomor 1 Bulan Juni 2020

\title{
PENINGKATAN PRESTASI BELAJAR PPKNPOKOK BAHASAN \\ PROSES PILKADES MELALUI PENERAPAN METODE \\ PEMBELAJARAN SIMULASI PADA SISWA KELAS VI SEKOLAH \\ DASAR NEGERI 03 PUCANGAN KECAMATAN \\ KARTASURA KABUPATEN SUKOHARJO \\ TAHUN PELAJARAN 2019-2020
}

\author{
Penulis \\ M.H. Sri Rahayu \\ Dosen Program Studi PPKn \\ FKIP-Univet Bantara sukoharjo \\ Email: srirahayu@gmail.com
}

\begin{abstract}
Abstrak
Penelitian ini bertujuan untuk mengetahui ada tidaknya peningkatan prestasi belajar mata pelajaran PPKn dengan materi Pilkades dengan menerapkan metode simulasi bagi siswa kelas VI SD Pucangan 03 Kecamatan kartasura kabupaten Sukoharjo Tahun Pelajaran 2019-2020. Penelitian ini adalah penelitian tindakan kelas, dengan subjek penelitiannya guru dan siswa kelas VI SD negeri pucangan 03, dan objeknya adalah Pilkades dan metode simulasi. Metode pengumpulan data menggunakan : observasi, tes, dan dokumentasi, Validitas data menggunakan trianggulasi sumber dan metode. Teknik analisis data menggunakan teknik analisis kuantitatif dan kualitatif. Hasil penelitian berdasarkan data awal diketahui banyak siswa yang mendapatkan skor di bawah KKM ketika diberikan pembelajaran PPKn materi Pilkades dengan menggunakan metode ceramah, selanjutnya dilakukan tindakan 1 hasilnya ada peningkatan yang signifikan tetapi kurang maksimal, selanjutnya dilakukan tindakan ke dua hasilnya sangat optimal. Kesimpulannya bahwa penggunaan metode simulasi dapat meningkatkan hasil belajar mata pelajaran PPKn dengan materi Pilkades bagi siswa kelas VI SD Pucangan 03 Kecamatan kartasura kabupaten Sukoharjo Tahun Pelajaran 2019-2020
\end{abstract}

Kata-Kata Kunci; Metode Simulasi dan Pilkades

JORNAL PROGDI PPKn, FKIP UNIVET BANTARA SUKOHARJO BEKERJA SAMA DENGAN ASSOSIASI PROFESI PENDIDIKAN PANCASILA DAN KEWARGANEGARAAN (AP3KNI) JAWA TENGAH 
CIVICS EDUCATION AND SOCIAL SCIENSE JOURNAL(CESSJ)

Volume 2 Nomor 1 Bulan Juni 2020

\title{
IMPROVEMENT OF PPKNPOKOK LEARNING ACHIEVEMENT OF PILKADES PROCESS THROUGH THE APPLICATION OF SIMULATION LEARNING METHOD IN CLASS VI STUDENTS OF STATE ELEMENTARY SCHOOL O3 PUCANGAN KECAMATAN KARTASURA KABUPATEN SUKOHARJO ACADEMIC YEAR 2019-2020
}

\author{
Author \\ M.H. Sri Rahayu \\ Lecturer of PPKn Study Program \\ FKIP-Univet Bantara Sukoharjo \\ Email: srirahayu@gmail.com
}

\begin{abstract}
This study aims to determine whether there is an increase in learning achievement of PPKn subjects with Pilkades material by applying simulation methods for Grade VI students of Pucangan 03 Elementary School Kartasura Subdistrict, Sukoharjo Regency 2019-2020 Academic Year. This research is a classroom action research, with the subject of the research being the teacher and grade VI students of SD Negeri Pucangan 03, and the object is Pilkades and simulation methods. Data collection methods use: observation, tests, and documentation. Data validity uses triangulation of sources and methods. Data analysis techniques using quantitative and qualitative analysis techniques. The results of the study are based on preliminary data known to many students who score below the KKM when given PPKn Pilkades material using the lecture method, followed by action 1 the results are significant but less than optimal, then the second action is very optimal. The conclusion is that the use of simulation methods can improve learning outcomes of PPKn subjects with Pilkades material for Grade VI students of Pucangan 03 Kartasura Subdistrict, Sukoharjo District, 2019-2020 Academic Year
\end{abstract}

\section{Key Words; Simulation and Pilkades Methods}


CIVICS EDUCATION AND SOCIAL SCIENSE JOURNAL(CESSJ)

Volume 2 Nomor 1 Bulan Juni 2020

\section{PENDAHULUAN}

Peran dunia pendidikan senantiasa harus dinamis dan tanggap dalam menghadapi dan mengantisipasi setiap perubahan yang terjadi pada Bangsa Indonesia. Saat ini bangsa Indonesia sedang berusaha meningkatkan kualitas pendidikan. Persyaratan penting untuk terwujudnya pendidikan bermutu adalah pelaksanaan proses pembelajaran oleh guru yang profesional, handal dalam layanan dan handal dalam keahliannya. Guru dituntut untuk membantu perkembangan siswa dalam segi kognitif, afektif dan psikomotor serta bukan semata mata memberikan sejumlah ilmu pengetahuan, tetapi juga harus menciptakan kondisi yang kondusif agar siswa belajar terus menerus. Unsur unsur tersebut menjadi terpadu dan terjalin dalam hubungan timbal balik antara guru dan siswa pada saat pengajaran berlangsung.

Kondisi pembelajaran PPKn pada siswa Kelas VI SD Negeri 03 Pacangan Kecamatan Kartasura, Kabupaten Sukoharjo tahun Pelajaran 20192020 sering menggunakan model pembelajaran ceramah. Model pembelajaran ini tidak dapat membangkitkan aktivitas siswa dalam belajar. Hal ini tampak dari perilaku siswa yang cenderung hanya mendengar dan mencatat pelajaran yang diberikan guru. Siswa tidak mau bertanya apalagi mengemukakan pendapat tentang materi yang diberikan.

Melihat kondisi ini, peneliti berusaha untuk mencarikan model pembelajaran lain, yang diharapkan proses pengajaran akan lebih hidup dan menjalin kerjasama diantara siswa, maka proses pembelajaran dengan paradigma lama harus diubah dengan paradigma baru yang dapat meningkatkan kreativitas siswa dalam berpikir, arah pembelajaran yang lebih kompleks tidak hanya satu arah sehingga proses belajar mengajar akan dapat meningkatkan kerjasama diantara siswa dengan guru, siswa dengan siswa maka dengan demikian siswa yang kurang akan dibantu oleh siswa yang lebih pintar sehingga proses pembelajaran lebih hidup dan hasilnya lebih baik. Pernyataan ini berdasarkan pendapat Nurhadi (2002: 5) bahwa, "Kegiatan pendidikan adalah suatu proses sosial yang tidak dapat terjadi tanpa interaksi antar pribadi. Belajar adalah suatu proses pribadi, tetapi juga proses sosial yang terjadi ketika masing masing orang berhubungan dengan yang lain dan membangun pengertian dan pengetahuan bersama”.

JORNAL PROGDI PPKn, FKIP UNIVET BANTARA SUKOHARJO BEKERJA SAMA DENGAN ASSOSIASI PROFESI PENDIDIKAN PANCASILA DAN KEWARGANEGARAAN (AP3KNI) JAWA TENGAH 
CIVICS EDUCATION AND SOCIAL SCIENSE JOURNAL(CESSJ)

Volume 2 Nomor 1 Bulan Juni 2020

Berdasarkan pandangan di atas, maka permasalahan yang muncul adalah bagaimana upaya guru untuk meningkatkan hasil balajar siswa dengan pendekatan yang tepat. Salah satu pendekatan pembelajaran yang yang dapat meningkatkan kreativitas siswa adalah pendekatan simulasi. Dengan pendekatan pembelajaran simulasil, siswa lebih memahami mengenai materi yang disampaikan oleh guru.

Metode pembelajaran simulasi adalah bentuk metode praktek yang sifatnya untuk mengembangkan ketermpilan peserta belajar (keterampilan mental maupun fisik/teknis). Metode ini memindahkan suatu situasi yang nyata ke dalam kegiatan atau ruang belajar karena adanya kesulitan untuk melakukan praktek di dalam situasi yang sesungguhnya. Misalnya: sebelum melakukan praktek penerbangan, seorang siswa sekolah penerbangan melakukan simulasi penerbangan terlebih dahulu (belum benar-benar terbang). Situasi yang dihadapi dalam simulasi ini harus dibuat seperti benar-benar merupakan keadaan yang sebenarnya (replikasi kenyataan).Contoh lainnya, dalam sebuah pelatihan fasilitasi, seorang peserta melakukan simulasi suatu metode belajar seakan-akan tengah melakukannya bersama kelompok dampingannya. Pendamping lainnya berperan sebagai kelompok dampingan yang benar-benar akan ditemui dalam keseharian peserta (ibu tani, bapak tani, pengurus kelompok, dsb.). Dalam contoh yang kedua, metode ini memang mirip dengan bermain peran. Tetapi dalam simulasi, peserta lebih banyak berperan sebagai dirinya sendiri saat melakukan suatu kegiatan/tugas yang benar-benar akan dilakukannya.

Berdasarkan latar belakang tersebut di depan peneliti tertarik untuk mengadakan penelitian dengan judul: "Peningkatan Prestasi Belajar PPKnPokok Bahasan Proses PILKADES Melalui Penerapan Metode Pembelajaran Simulasi Pada Siswa Kelas VI SD 03 Pucangan Kecamatan kartasura kabupaten Sukoharjo tahun Pelajaran 2019-2020”.

\section{KAJIAN PUSTAKA}

Sebelum membicarakan pengertian prestasi belajar, terlebih dahulu akan dikemukakan apa yang dimaksud dengan belajar. Para pakar pendidikan mengemukakan pengertian yang berbeda antara satu dengan yang lainnya, namun demikian selaku mengacu pada prinsip yang sama yaitu setiap orang yang 
CIVICS EDUCATION AND SOCIAL SCIENSE JOURNAL(CESSJ)

Volume 2 Nomor 1 Bulan Juni 2020

melakukan proses belajar akan mengalami suatu perubahan dalam dirinya. Menurut Slameto (2005:2) belajar adalah "suatu proses usaha yang dilakukan seseorang untuk memperoleh suatu perubahan tingkah laku yang baru secara keseluruhan, sebagai hasil pengalamannya sendiri dalam interaksi dengan lingkungannya." Selanjutnya Winkel (2000:53) belajar adalah "suatu aktivitas mental/psikis yang berlangsung dalam interaksi yang aktif dengan lingkungan, yang menghasilkan perubahan-perubahan dalam pengetahuan, pemahaman, keterampilan dan nilai sikap". Perubahan itu bersifat secara relatif konstant." Kemudian Omar Hamalik (2002:28) mendefinisikan belajar adalah "suatu pertumbuhan atau perubahan dalam diri seseorang yang dinyatakan dalam cara-cara bertingkah laku yang baru berkat pengalaman dan latihan."

Kemampuan intelektual siswa sangat menentukan keberhasilan siswa dalam memperoleh prestasi. Untuk mengetahui berhasil tidaknya seseorang dalam belajar maka perlu dilakukan suatu evaluasi, tujuannya untuk mengetahui prestasi yang diperoleh siswa setelah proses belajar mengajar berlangsung.

Adapaun prestasi dapat diartikan hasil diperoleh karena adanya aktivitas belajar yang telah dilakukan. Namun banyak orang beranggapan bahwa yang dimaksud dengan belajar adalah mencari ilmu dan menuntut ilmu. Ada lagi yang lebih khusus mengartikan bahwa belajar adalah menyerap pengetahuan. Belajar adalah perubahan yang terjadi dalam tingkah laku manusia. Proses tersebut tidak akan terjadi apabila tidak ada suatu yang mendorong pribadi yang bersangkutan.

Prestasi belajar merupakan hal yang tidak dapat dipisahkan dari kegiatan belajar, karena kegiatan belajar merupakan proses, sedangkan prestasi merupakan hasil dari proses belajar. Memahami pengertian prestasi belajar secara garis besar harus bertitik tolak kepada pengertian belajar itu sendiri. Untuk itu para ahli mengemukakan pendapatnya yang berbeda-beda sesuai dengan pandangan yang mereka anut. Namun dari pendapat yang berbeda itu dapat kita temukan satu titik persamaan. Sehubungan dengan prestasi belajar, Poerwanto (2003:28) memberikan pengertian prestasi belajar yaitu "hasil yang dicapai oleh seseorang dalam usaha belajar sebagaimana yang dinyatakan dalam raport." Selanjutnya Winkel (2000:162) mengatakan bahwa "prestasi belajar adalah suatu bukti keberhasilan belajar atau kemampuan seseorang siswa dalam melakukan kegiatan belajarnya sesuai dengan bobot yang dicapainya.” Sedangkan menurut S. Nasution (2004:17) prestasi belajar adalah: "Kesempurnaan yang dicapai seseorang dalam berfikir, 
CIVICS EDUCATION AND SOCIAL SCIENSE JOURNAL(CESSJ)

Volume 2 Nomor 1 Bulan Juni 2020

merasa dan berbuat. Prestasi belajar dikatakan sempurna apabila memenuhi tiga aspek yakni: kognitif, affektif dan psikomotor, sebaliknya dikatakan prestasi kurang memuaskan jika seseorang belum mampu memenuhi target dalam ketiga kriteria tersebut."

Berdasarkan pengertian di atas, maka dapat dijelaskan bahwa prestasi belajar merupakan tingkat kemanusiaan yang dimiliki siswa dalam menerima, menolak dan menilai informasi-informasi yang diperoleh dalam proses belajar mengajar. Prestasi belajar seseorang sesuai dengan tingkat keberhasilan sesuatu dalam mempelajari materi pelajaran yang dinyatakan dalam bentuk nilai atau raport setiap bidang studi setelah mengalami proses belajar mengajar.

Prestasi belajar siswa dapat diketahui setelah diadakan evaluasi. Hasil dari evaluasi dapat memperlihatkan tentang tinggi atau rendahnya prestasi belajar siswa.

Untuk mencapai prestasi belajar siswa sebagaimana yang diharapkan, maka perlu diperhatikan beberapa faktor yang mempengaruhi prestasi belajar antara lain; faktor yang terdapat dalam diri siswa (faktor intern), dan faktor yang terdiri dari luar siswa (faktor ekstern). Faktor-faktor yang berasal dari dalam diri anak bersifat biologis sedangkan faktor yang berasal dari luar diri anak antara lain adalah faktor keluarga, sekolah, masyarakat dan sebagainya.

The Liang Gie (2001:12) membagi fase belajar ke dalam dua fase yaitu fase persiapan belajar dan fase proses belajar. Dalam tiap-tiap fase tersebut cara atau teknik belajar tersendiri.

\section{1) Fase Persiapan Belajar}

Fase ini merupakan fase sebelum belajar, landasar utama bagi pembentukan cara belajar yang baik adalah sikap mental yang baik, yaitu sikap mental yang ditumbuhkan dan dipelihara dengan sebaik-baiknya agar siswa mempunyai kesadaran berupa kesediaan mental. Tanpa kesediaan mental siswa dalam belajar tidak akan bertahan menghadapi berbagai macam kesukaran, terutama pada saat siswa dihadapi paa berbagai masalah yang harus dipecahkan.

Sikap mental yang perlu diusahakan oleh setiap siswa dalam rangka persiapan belajar sekurang-kurangnya mencakup empat segi, yaitu: Tujuan belajar, minat terhadap pelajaran, kepercayaan paa diri sendiri dan keuletan. 
CIVICS EDUCATION AND SOCIAL SCIENSE JOURNAL(CESSJ)

Volume 2 Nomor 1 Bulan Juni 2020

\section{a) Tujuan Belajar}

Belajar di sekolah perlu diarahkan pada suatu cita-cita tertentu, cita-cita yang diperjuangkan dengan berbagai macam kegiatan belajar. Tujuan belajar perlu diketahui oleh siswa, agar siswa siap menerima materi pelajaran, seperti apa yang dijelaskan Winarno Surachman (2004:99) bahwa: "Tujuan itu penting anda ketahui terlebih dahulu, sebab jika anda sudah mengetahui tujuan itu maka mental anda pun akan siap menerima, mengolah dan mengatur semua mata pelajaran sesuai dengan tujuan itu."

b) Minat terhadap mata pelajaran

Setiap siswa seharusnya menaruh minat yang besar terhadap mata pelajaranyang mereka ikuti, karena minat selain memusatkan pikiran juga akan menimbulkan kegembiraan dalam usaha belajar, seperti yang kemukakan oleh The Liang Gie (2001:12) adalah "keriangan hati akan memperbesar kemampuan belajar seseorang dan juga membentunya tidak melupakan apa yang dipelajarinya itu."

Materi pelajaran dapat dipelajari dengan baik bila siswa dapat memusatkan pikirannya dan menyenangi materi pelajaran tersebut. Siswa kurang berhasil dalam menerima materi pelajaran itu disebabkan siswa itu tidak tertarik dengan materi pelajaran yang disampaikan.

c) Kepercayaan kepada diri sendiri

Setiap siswa perlu yakin mereka mempunyai kemampuan kepercayaan kepada diri sendiri perlu dipupuk sebagai salah satu kesiapan sepenuhnya bahwa tidak ada mata pelajaran yang tidak dapat dipahami bila ia mau belajar dengan giat setiap hari.

\section{d) Keuletan}

Hidup seorang siswa selama belajar di sekolah penuh kesukarankesukaran, oleh karena itu setiap siswa perlu memiliki keuletan baik jasmani maupun rohani. Untuk memupuk keuletan tersebut hendaknya siswa selalu menganggap setiap persoalan muncul sebagai tantangan yang harus diatasi.

Materi pelajaran yang diberikan guru di sekolah masih mengharuskan siswa melaksanakan aktifitas mental, untuk menanamkan konsep pelajaran yang lebih baik. Untuk itu Herman Hudoyo (2004:15) menyarankan bahwa: "Belajar haruslah aktif, tidak sekedar pasif saja menerima apa yang 
CIVICS EDUCATION AND SOCIAL SCIENSE JOURNAL(CESSJ)

Volume 2 Nomor 1 Bulan Juni 2020

diberikan. Dapat mengharapkan jika siswa aktif melibatkan diri dalam menemukan suatu prinsip dasar, anak itu akan mengerti konsep yang lebih baik, ingatannya lebih lama dan akan mampu menggunakan konsep tersebut dikonteks yang lain."

\section{2) Fase Proses Belajar}

Fase ini sangat menentukan seorang siswa berhsail tidaknya di sekolah, pada fase proses belajar ini dituntut kepada siswa untuk menerapkan cara-cara belajar yang sebaik mungkin. Hal-hal yang perlu diperhatikan dalam fase ini antara lain:

a) Pedoman dalam belajar

Pedoman dalam belajar perlu dibuat untuk menjadi petunjuk dalam melakukan kegiatan belajar. Karena setiap usaha apapun tentu ada azasazas yang dijadikan sebagai pedoman demi suksesnya usaha tersebut. Demikian pula dalam belajar, The Liang Gie (2001:13) mengemukakan bahwa: "Prinsip-prinsip belajar itu sekurang-kurangnya menyangkut tiga hal, yaitu keteraturan, disiplin dan konsentrasi."

Keteraturan dalam belajar sangat penting artinya, bila siswa ingin belajar dengan baik, maka hendaknya siswa dapat menjadikan keteraturan di dalam belajar itu sebagai hal pokok sesuai dengan saran Al-Falasany (2002:15) bahwa: "Keteraturan belajar adalah pangkal utama dari cara belajar yang baik."

Di dalam belajar siswa akan berhadapan dengan bermacam-macam rintangan yang dapat menangguhkan usaha belajarnya, tetapi dengan mendisiplinkan dirinya sendiri ia akan dapat mengatasi semua hal itu, AlFalasany (2002:15) mengemukakan bahwa dengan kemauan yang keras dan dengan disiplin ia akan dapat menjauhi godaan dan gangguan yang mendorongnya malas belajar, ogah-ogahan dan menunda-nunda studi.

Setelah faktor keteraturan dan displin di dalam belajar, maka konsentrasi juga sangat diperlukan pada saat berada dalam proses belajar perlu konsentrasi, tanpa konsentrasi ia tidak mungkin dapat menguasai materi pelajaran. 
CIVICS EDUCATION AND SOCIAL SCIENSE JOURNAL(CESSJ)

Volume 2 Nomor 1 Bulan Juni 2020

\section{b) Cara mengikuti pelajaran}

Untuk dapat mengikuti pelajaran dengan baik di sekolah, maka diharapkan kepada siswa agar dapat memusatkan pikiran dan perhatiannya pada materi pelajaran yang sedang disajikan oleh guru. ET Ruseffendi (2002:18) mengemukakan bahwa: "Anak-anak harus belajar berbuat sendiri dan merasakan sendiri. Makin banyak indera yang dipakai makin efedien anak belajar."

Siswa akan memperoleh pengalaman belajar yang lebih banyak bila ia dapat mengikuti pelajaran dengan tertib, penuh perhatian, mencatat dengan baik, serta mau bertanya jika ada penjelasan yang kurang dimengerti. Dengan demikian dapat diharapkan, jika siswa aktif melibatkan diri dalam menemukan prinsip-prinsip dasar siswa itu akan mengerti konsep yang lebih baik.

Namun untuk mempermudah siswa memahami konsep-konsep yang diajarkan di sekolah, sebaiknya siswa sudah mempersiapkan dirinya dengan pengetahuan tentang materi-materi sebelumnya, karena Herman Hudoyo (2002:18) menekankan bahwa: "Pada waktu siswa mempelajari sesuatu konsep yang benar-benar baru, untuk mudah memahami konsepkonsep tersebut, siswa perlu berorientasi dengan pengalaman yang lampau."

c) Cara mengulangi materi pelajaran/membaca buku

Setelah di sekolah siswa mengikuti pelajaran dengan baik, tentu usaha siswa untuk mendapat pengertian tentang konsep materi pelajaran dengan baik tidak cukup sampai di sini, tetapi siswa perlu lagi mengkaji, mengulangi dan membaca kembali materi tersebut.

Belajar memang tidak lepas dari membaca dan ternyata membaca sebenarnya tidak sesederhana yang kita bayangkan. Membaca mempunyai teknik-teknik tersendiri, sebagaimana juga menulis. Dengan mengikuti teknik membaca sistimatis dan cepat, kita dapat menghemat waktu dan belajar lebih banyak.

Banyak siswa sekolah menengah maupun mahasiswa masih mempunyai kebiasaan yang jelek. Mereka membaca sangat lamban, kurang memahami makna kata dan ungkapan-ungkapan tertentu lebih-lebih dengn bacaan 
CIVICS EDUCATION AND SOCIAL SCIENSE JOURNAL(CESSJ)

Volume 2 Nomor 1 Bulan Juni 2020

yang berat. Di samping itu tidak dapat merefleksikan apa yang telah dibaca.

Kesukaran belajar banyak ditentukan oleh keterampilan membaca. Memang banyak faktor yang menentukannya. Hal pertama kali yang harus diperhatikan adalah jarak mata dengan buku atau tulisan. Hal ini sesuai dengan yang dikemukakan oleh Sudarmanto (2003:35) yaitu: "Jarak membaca yang baik adalah 16 inci $( \pm 30 \mathrm{~cm})$. Bila dalam membaca jarak itu tidak dapat dijangkau maka ada ketidak-beresan dengan mata." Adapun tujuan yang dihadapkan dalam usaha mengulangi kembali pelajaran di rumah itu adalah untuk memperkuat ingatan siswa terhadap materi pelajaran yang akan digunakan untuk memecahkan masalah atau soal-soal. Dalam hal ini Herman Hudoyo (2002:27) menegaskan bahwa: "Ingatan memegang peranan penting di dalam belajar jika siswa harus mencari jalan untuk menyelesaikan suatu masalah.”

Metode simulasi adalah metode yang diberikan kepada siswa, agar siswa dapat menggunakan sekumpulan fakta, konsep, dan strategi tertentu. Penggunaan metode tersebut memberi kesempatan kepada siswa untuk berinteraksi sehingga dapat mengurangi rasa takut. Metode simulasi adalah bentuk metode praktek yang sifatnya untuk mengembangkan ketermpilan peserta belajar (keterampilan mental maupun fisik/teknis). Metode ini memindahkan suatu situasi yang nyata ke dalam kegiatan atau ruang belajar karena adanya kesulitan untuk melakukan praktek di dalam situasi yang sesungguhnya. Misalnya: sebelum melakukan praktek penerbangan, seorang siswa sekolah penerbangan melakukan simulasi penerbangan terlebih dahulu (belum benar-benar terbang). Situasi yang dihadapi dalam simulasi ini harus dibuat seperti benar-benar merupakan keadaan yang sebenarnya (replikasi kenyataan).

Contoh lainnya, dalam sebuah pelatihan fasilitasi, seorang peserta melakukan simulasi suatu metode belajar seakan-akan tengah melakukannya bersama kelompok dampingannya. Pendamping lainnya berperan sebagai kelompok dampingan yang benar-benar akan ditemui dalam keseharian peserta (ibu tani, bapak tani, pengurus kelompok, dsb.). Dalam contoh yang kedua, metode ini memang mirip dengan bermain peran. Tetapi dalam simulasi, peserta lebih banyak berperan sebagai dirinya sendiri saat melakukan suatu kegiatan/tugas yang benar- 
CIVICS EDUCATION AND SOCIAL SCIENSE JOURNAL(CESSJ)

Volume 2 Nomor 1 Bulan Juni 2020

benar akan dilakukannya. Metode simulasi cenderung lebih dinamis dalam menanggapi gejala fisik dan sosial, karena melalui metode ini seolah-olah siswa melakukan hal-hal yang nyata ada. Dengan mensimulasikan sebuah kasus atau permasalahan, seseorang akan lebih menjiwai keberadaann

Keunggulan metode simulasi antara lain adalah : Simulasi merupakan alat motivasi belajar yang sangat baik, Keberhasilan simulasi menuntut penggunaan beberapa keterampilan dan teknik dan praktek, hubungan antara belajar dan hiburan, , Simulasi penuh cara untuk membuat topik dari kehidupan, , Keberhasilan simulasi sangat menyenangkan (rewarding) bagi guru. Mereka dapat duduk dibelakang menikmati permainan siswa yang penuh dengan keaktifan belajar. Pendek kata, simulasi memberi kesempatan kepada siswa untuk mendekatkan diri dengan pengalaman kehidupan yang nyata. Simulasi merupakan metode yang baik untuk pembelajaran moral, etik, klarifikasi nilai, dan pendidikan sikap.

Kelemahan metode simulasi antara lain adalah : Bagi siswa yang penakut, penerapan metode ini menjadi hal yang tidak menyenangkan sehingga enggan untuk bersimulasi, Sebaliknya bagi siswa yang pandai, dan yang senang berbicara cenderung menguasai proses simulasi, Bagi siswa yang susah mengeluarkan pendapat, hal ini merupakan metode yang paling menyusahkan.

Menurut Ornstein rambu-rambu dalam penggunaan dan pelaksanaan simulasi. Rambu-rambu yang dimaksud antara lain berikut ini. Setiap penggunaan dan atau pelaksanaan simulasi harus didasarkan atas tujuan pembelajaran. Tujuan penggunaan simulasi adalah memungkinkan siswa untuk memahami ciri-ciri masalah dan bagaimana memecahkan masalah. Ornstein, (1990:357)

Simulasi digunakan untuk pembelajaran berfikir dan sarana sosialisasi bagi siswa untuk kelas rendah. Simulasi harus dipandang sebagai kegiatan untuk mendapatkan pengalaman belajar. Penggunaan simulasi harus berhubungan dengan isi mata pembelajaran (keterampilan, pemahaman konsep, dan nilai), dan isi mata pembelajaran tersebut harus berkaitan dengan kenyataan hidup yang sebenarnya. Hanya variabel, hal, atau masalah yang yang signifikan yang disimulasikan. Dalam simulasi, peran yang dimainkan oleh siswa harus jelas. Jika hal-hal yang telah terjadi di masyarakat disimulasikan, maka variabel atau latarbelakang yang ada dalam situasi kehidupan masyarakat tersebut perlu diperkenalkan terlebih dahulu.

Pada saat sejumlah siswa pemain bersimulasi, dan yang lain sebagai pengamat, maka yang lain bertugas untuk mengkaji simulasi. Pemeranan simulasi 
CIVICS EDUCATION AND SOCIAL SCIENSE JOURNAL(CESSJ)

Volume 2 Nomor 1 Bulan Juni 2020

harus singkat dan jelas. Guru harus mampu menjawab pertanyaan siswa, sebelum simulasi dimulai. Peran mudah dipahami dan mudah diperankan.

Pada akhir simulasi, diskusi adalah penting bagi siswa untuk klarifikasi keterampilan, konsep, dan nilai yang telah dipelajari. Akhir simulasi, diskusi tentang studi kasus, gambaran tentang pengalaman siswa, terapan tentang apa yang diamati dalam kehidupan nyata di masyarakat, saran-saran untuk belajar selanjutnya.

PPKn merupakan salah satu mata pelajaran yang dapat membentuk diri yang beragam dari segi agama, sosio-kultural, bahasa, usia, untuk menjadi warga negara yang cerdas, terampil dan berkarakter yang dilandasi oleh UUD 1945. Hal ini sesuai dengan yang dikemukakan oleh Depdiknas (2005: 34) bahwa: PPKn merupakan mata pelajaran yang secara umum bertujuan untuk mengembangkan potensi individu warga negara Indonesia, sehingga memiliki wawasan, sikap, dan keterampilan kewarganegaraan yang memadai dan memungkinkan untuk berpartisipasi secara cerdas dan bertanggung jawab dalam berbagai kehidupan bermasyarakat, berbangsa dan bernegara.

Berdasarkan pendapat di atas jelas bagi kita bahwa PPKn bertujuan mengembangkan potensi individu warga negara, dengan demikian maka seorang guru PKPn haruslah menjadi guru yang berkualitas dan profesional, sebab jika guru tidak berkualitas tentu tujuan PKPn itu sendiri tidak tercapai. Secara garis besar mata pelajaran Kewarganegaraan memiliki 3 dimensi yaitu:

1) Dimensi Pengetahuan Kewarganegaraan (Civics Knowledge) yang mencakup bidang politik, hukum dan moral.

2) Dimensi Keterampilan Kewarganegaraan (Civics Skills) meliputi keterampilan partisipasi dalam kehidupan berbangsa dan bernegara.

3) Dimensi Nilai-nilai Kewarganegaraan (Civics Values) mencakup antara lain percaya diri, penguasaan atas nilai religius, norma dan moral luhur. (Depdiknas $2003: 4)$

Berdasarkan uraian di atas peneliti berpendapat bahwa dalam mata pelajaran PPKn seorang siswa bukan saja menerima pelajaran berupa pengetahuan, tetapi pada diri siswa juga harus berkembang sikap, keterampilan dan nilai-nilai. Sesuai dengan Depdiknas (2005 : 33) yang menyatakan bahwa tujuan PPKn untuk setiap jenjang pendidikan yaitu mengembangkan kecerdasan warga negara yang 
CIVICS EDUCATION AND SOCIAL SCIENSE JOURNAL(CESSJ)

Volume 2 Nomor 1 Bulan Juni 2020

diwujudkan melalui pemahaman, keterampilan sosial dan intelektuan, serta berprestasi dalam memecahkan masalah di lingkungannya.

Untuk mencapai tujuan PPKntersebut, maka guru berupaya melalui kualitas pembelajaran yang dikelolanya, upaya ini bisa dicapai jika siswa mau belajar. Dalam belajar inilah guru berusaha mengarahkan dan membentuk sikap serta perilaku siswa sebagai mana yang dikehendaki dalam pembelajaran PPKn.

Sedangkan Dwi Santoso (1994:111) menyatakan bahwa "PPKnadalah pendidikan untuk memberi bekal; pengetahuan dan kemampuan dasar yang berkenaan dengan hubungan antar warganegara dengan negara serta pendidikan pendahuluan bela negara. Menurut pendapat Ali Fais (2000:3) menyebutkan bahwa "PPKnadalah pendidikan untuk mengarahkan pada pembentukan moral yang diharapkan diwujudkan dalam perilaku sehari-hari.

Berdasarkan definisi-definisi di atas dapat diambil kesimpulan bahwa "PPKnadalah pendidikan untuk mengarahkan pembentukan moral yang diwujudkan dalam perilaku sehari-hari dan membekali pengetahuan serta kemampuan dasar berkenaan dengan hubungan antar warga negara dengan negara serta pendahuluan bela negara. Melalui PPKnini para siswa diharapkan mampu mengembangkan potensinya baik sebagai pribadi, anggota masyarakat, bangsa dan negara, maupun sebagai anggota masyarakat dunia.

Menurut Depdiknas (2005:21) fungsi pelajaran PPKn adalah : Melestarikan dan mengembangkan nilai moral Pancasila secara dinamis dan terbuka, yaitu nilai moral Pancasila yang dikembangkan dan mampu menjawab tantangan perkembangan yang terjadi dalam masyarakat, tanpa kehilangan jati diri sebagai bangsa Indonesia, yang merdeka, bersatu dan berdaulat. Mengembangkan dan membina siswa menuju manusia Indonesia seutuhnya yang sadar politik, hukum dan konstitusi Negara Kesatuan Republik Indonesia berdasarkan Pancasila. Membina pemahaman dan kesadaran terhadap hubungan antar warga negara dengan negara, antar warganegara dengan sesama warganegara, dan pendidikan pendahuluan bela negara agar mengetahui dan mampu melaksanakan dengan baik hak dan kewajibannya sebagai warganegara. Membekali siswa dengan sikap dan perilaku yang berdasarkan nilai-nilai moral Pancasila dan UUD 1945 dalam kehidupan sehari-hari.

Dengan memperhatikan fungsi PPKntersebut maka dapat diambil kesimpulan bahwa melalui PPKnsiswa diarahkan untuk dapat berperilaku dan melestarikan nilai moral Pancasila, membina hubungan antara sesama manusia di 
CIVICS EDUCATION AND SOCIAL SCIENSE JOURNAL(CESSJ)

Volume 2 Nomor 1 Bulan Juni 2020

dunia, dan secara sadar melaksanakan hak maupun kewajibannya sebagai warganegara Indonesia.

\section{METODE}

Penelitian ini termasuk penelitian tindakan kelas (PTK) yaitu penelitian yang dimaksudkan untuk memberikan informasi bagaimana tindakan yang tepat untuk meningkatkan keaktifan siswa, sehingga penelitian ini difokuskan pada tindakan-tindakan sebagai usaha untuk meningkatkan keaktifan siswa dalam belajar bahasa Indonesia (Zainal Aqib, 2006: 136).

Penelitian kelas merupakan kegiatan pemecahan masalah yang dimulai dari : a) perencanaan (planning), b) pelaksanaan (action), c) pengumpulan data (observing), d) menganalisis data atau informasi untuk memutuskan sejauh mana kelebihan atau kelemahan tindakan tersebut (reflecting). PTK bercirikan perbaikan terus menerus sehingga kepuasan peneliti menjadi tolak ukur berhasilnya (berhentinya) siklus-siklus tersebut.

Setelah dilakukan refleksi yang mencakup analisis, sintesis dan penelitian terhadap hasil pengamatan serta hasil tindakan, biasanya muncul permasalahan yang perlu mendapat perhatian sehingga pada gilirannya perlu dilakukan perencanaan ulang. Penelitian ini dilakukan secara kolaboratif antara guru sejawat dan peneliti. Kegiatan perencanaan awal dimulai dari melakukan studi pendahuluan. Pada kegiatan ini juga mendiskusikan cara melakukan tindakan pembelajaran dan bagaimana cara melakukan pengamatannya.

Subjek penelitian ini adalah siswa kelas VI SD Negeri 03 Pacangan Kecamatan Kartasura, Kabupaten Sukoharjo tahun Pelajaran 2019-2020dengan pertimbangan bahwa siswa pada sekolah ini memiliki kemampuan yang heterogen. Adapun jumlah siswa yang diteliti sebanyak 26 siswa yang terdiri dari laki-laki sebanyak 11 orang dan perempuan sebanyak 15 orang. Objek penelitiannya Pilkades dan Metode simulasi. Data dalam penelitian bersumber dari interaksi guru dan siswa dalam pembelajaran PPn dan berupa data tindakan belajar atau perilaku belajar yang dihasilkan dari tindakan yang mengajar. Pengambilan data dilakukan dengan: Metode Observasi, Metode Tes dan Metode Dokumentasi

\section{A. Teknik Analisis Data}

Pada penelitian tindakan kelas ini, data dianalisis sejak tindakan pembelajaran dilakukan dan dikembangkan selama proses refleksi sampai proses penyusunan laporan. Untuk kesinambungan dan kedalaman dalam pengajaran data dalam penelitian ini digunakan analisis deskriptif kritis. Data yang dianalisis secara deskriptif kritis dengan analisis interaktif yang terdiri dari 
CIVICS EDUCATION AND SOCIAL SCIENSE JOURNAL(CESSJ)

Volume 2 Nomor 1 Bulan Juni 2020

reduksi data, penyajian data, dan penarikan kesimpulan dilakukan dalam bentuk interaktif dengan pengumpulan data sebagai suatu proses siklus.

\section{B. Indikator Kinerja}

Indikator kinerja dalam penelitian tindakan kelas ini diukur berdasarkan hal-hal sebagai berikut:

1. Hasil evaluasi pembelajaran PKn yang diperoleh siswa di atas Kriteria Ketuntasan Mengajar (KKM) yaitu 65.

2. Keaktifan siswa dalam kegiatan pembelajaran berjalan sesuai dengan tujuan pembelajaran.

3. Minat atau motivasi siswa dalam mengikuti kegiatan pembelajaran terbentuk.

Prosedur Penelitian dilakukan dengan menggunakan siklus-siklus :

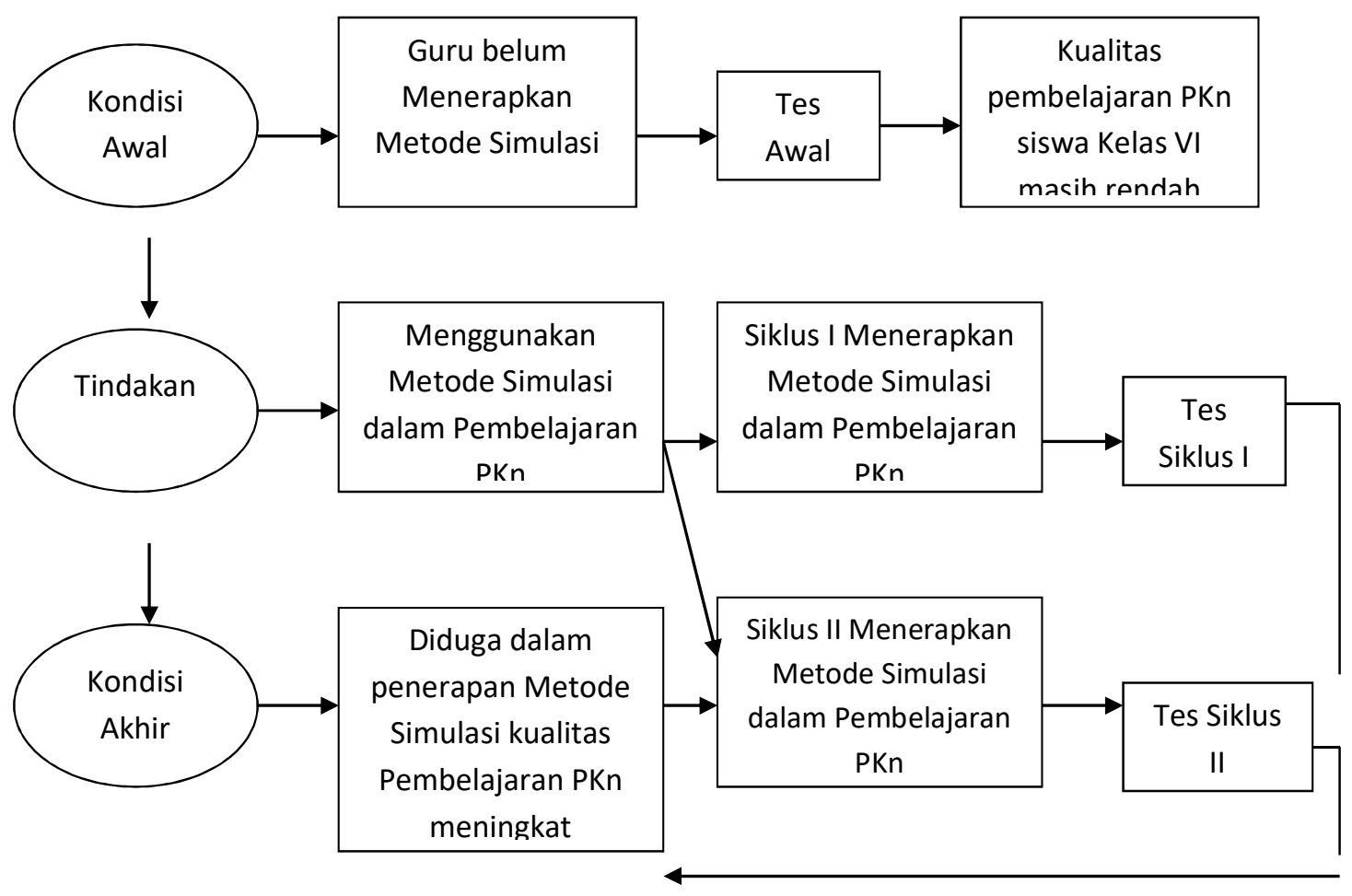

JORNAL PROGDI PPKn, FKIP UNIVET BANTARA SUKOHARJO BEKERJA SAMA DENGAN ASSOSIASI PROFESI PENDIDIKAN PANCASILA DAN KEWARGANEGARAAN (AP3KNI) JAWA TENGAH 
CIVICS EDUCATION AND SOCIAL SCIENSE JOURNAL(CESSJ)

Volume 2 Nomor 1 Bulan Juni 2020

\section{HASIL PENELITIAN DAN PEMBAHASAN}

\section{Deskripsi Kondisi Awal}

Berdasarkan hasil observasi pada siswa Kelas VI SD Negeri 03 Pacangan Kecamatan Kartasura, Kabupaten Sukoharjo tahun Pelajaran 2019-2020 menunjukkan bahwa sebagian besar siswa kurang memahami pada pokok bahasan proses PILKADES dan Pilkada. Kondisi tersebut dapat peneliti jelaskan ketika guru mengadakan kegiatan pembelajaran, sebagian besar siswa belum dapat menjelaskan beberapa hal yang berkaitan dengan PILKADES seperti : tujuan PILKADES tata cara pelaksanaan PILKADES tata cara pelaksanaan PILKADES tata cara pelaksanaan Pilkada, asas Pilkades .

Hal tersebut berdasarkan hasil pengamatan peneliti disebabkan karena guru dalam mengajar PPKn masih menggunakan metode ceramah, sehingga siswa kurang dapat menyerap materi yang disampaikan oleh guru.

Berkaitan dengan kondisi tersebut peneliti berusaha mengatasi berbagai kendala-kendala dalam pembelajaran PPKn khususnya pokok bahasan proses PILKADES dengan metode pembelajaran simulasi. Dengan menggunakan metode pembelajaran simulasi diharapkan siswa dapat lebih mudah menerima materi yang diajarkan oleh guru, sebab dalam pembelajaran tersebut siswa dapat memperagakan sesuatu kejadian sesuai dengan keadaan aslinya.

Adapun hasil evaluasi belajar PKn siswa Kelas VI SD Negeri 03

Pacangan Kecamatan Kartasura, Kabupaten Sukoharjo tahun Pelajaran 2019-2020pada kondisi awal adalah sebagai berikut: 
CIVICS EDUCATION AND SOCIAL SCIENSE JOURNAL(CESSJ)

Volume 2 Nomor 1 Bulan Juni 2020

TABEL I

HASIL EVALUASI KONDISI AWAL

\begin{tabular}{|l|l|c|c|l|}
\hline No. & \multicolumn{1}{|c|}{ Nama } & Nilai & KKM & Keterangan \\
\hline 1 & ROHKANI & 78 & 65 & Tuntas \\
\hline 2 & BUDIMAN & 53 & 65 & Tidak Tuntas \\
\hline 3 & SITI SUWARNI & 63 & 65 & Tidak Tuntas \\
\hline 4 & JOKO RAHARJO & 63 & 65 & Tidak Tuntas \\
\hline 5 & ALDO FIRMANTO & 55 & 65 & Tidak Tuntas \\
\hline 6 & ENDANG SAYEKTI & 68 & 65 & Tuntas \\
\hline 7 & CICIH KURNIASIH & 60 & 65 & Tidak Tuntas \\
\hline 8 & EDI WIYONO & 74 & 65 & Tuntas \\
\hline 9 & JOKO SANTOSO & 63 & 65 & Tidak Tuntas \\
\hline 10 & RINI PALUPI & 62 & 65 & Tidak Tuntas \\
\hline 11 & BAMBANG NUGROHO & 45 & 65 & Tidak Tuntas \\
\hline 12 & LINDAWATI & 78 & 65 & Tuntas \\
\hline 13 & FEBIA NURHAYATI & 84 & 65 & Tuntas \\
\hline 14 & FAREL YULIANTO & 42 & 65 & Tidak Tuntas \\
\hline 15 & OKTA NIRWANDA & 63 & 65 & Tidak Tuntas \\
\hline 16 & SARAH YULIANA & 60 & 65 & Tidak Tuntas \\
\hline 17 & DADANG GUNAWAN & 47 & 65 & Tidak Tuntas \\
\hline 18 & VONI ERNITA WATI & 57 & 65 & Tidak Tuntas \\
\hline 19 & GEORGE YUNIANTO & 67 & 65 & Tuntas \\
\hline 20 & YENI BONDOWATI & 57 & 65 & Tidak Tuntas \\
\hline 21 & JAJANG SETYAWAN & 58 & 65 & Tidak Tuntas \\
\hline 22 & NINA KURNIAWATI & 62 & 65 & Tidak Tuntas \\
\hline 23 & WAWAN JUTAWAN & 50 & 65 & Tidak Tuntas \\
\hline 24 & JONI INDRIAS & 67 & 65 & Tuntas \\
\hline 25 & TUTIK LESTARI & 64 & 65 & Tidak Tuntas \\
\hline 26 & DEDI FIRMANSYAH & 61 & 65 & Tidak Tuntas \\
\hline & Jumlah & 1601 & & \\
\hline & Rata-rata & 61,58 & & \\
\hline
\end{tabular}


CIVICS EDUCATION AND SOCIAL SCIENSE JOURNAL(CESSJ)

Volume 2 Nomor 1 Bulan Juni 2020

Berdasarkan hasil evaluasi pembelajaran PKn siswa Kelas VI SD Negeri 03 Pacangan Kecamatan Kartasura, Kabupaten Sukoharjo tahun Pelajaran 2019-2020menunjukkan bahwa nilai rata-rata kelas dari 26 siswa sebeesar 61,58 dengan presentase ketuntasan yaitu $26,92 \%$.

\section{Deskripsi Siklus I}

1) Perencanaan

a) Membuat rencana pelaksanaan pembelajaran

b) Menyiapkan alat peraga pelajaran mengenai proses pemilian umum, khususnya pemungutan suara, diantaranya adalah kertas karton untuk bilik suara, sepidol, kartu pemilih, serta blangko yang berisi nama-nama dan logo partai politik.

c) Menyiapkan lembar kerja siswa

d) Menyiapkan lembar pengamatan

2) Pelaksanaan

Berikut merupakan proses kegiatan pembelajaran PPKn pokok bahasan proses PILKADES dengan menggunakan metode pembelajaran simlulasi.

a) Pembukaan

(1) Guru memberikan salam diikuti dengan doa

Sebelum guru memulai pembelajaran, guru terlebih dahulu mengucapkan salam, yang dilanjutkan denggan berdoa yang dipimpin oleh ketua kelas.

(2) Guru mengabsen kehadiran siswa

Setelah para siswa selesai berdoa, guru mengabsen kehadiran siswa, hal ini sangat penting sebab dengan melakukan absensi guru mengetahui siapa-siapa saja yang tidak masuk kelas. Pada pelaksanaan pembelajaran Siklus I ini, semua siswa masuk.

(3) Guru memberikan apersepsi kepada siswa

Selanjutnya setelah kegiatan mengabsensi siswa dilakukan, guru mengajak siswa untuk menyanyi bersama-sama Indonesia Raya. Hal ini dilakukan untuk memberi motivasi dan rasa senang pada diri siswa sebelum pembelajaran dimulai. 
CIVICS EDUCATION AND SOCIAL SCIENSE JOURNAL(CESSJ)

Volume 2 Nomor 1 Bulan Juni 2020

2) Inti

(1) Fase orientasi

Sebelum guru memberikan pembelajaran simulasi, guru memberikan penjelasan tentang topik dan memberikan gambaran tentang simulasi. Dalam hal ini guru memberikan penjelasan mengenai proses pelaksanaan PILKADES tahun 2019 yang dilaksanakan di Indonesia.

Adapun penjelasan materinya adalah sebagai berikut:

\section{Hasil dan Pembahasan}

\section{Hasil dan Pembahasan Siklus I}

Berdasarkan hasil evaluasi pembelajaran siklus I pelajaran PKn pokok bahasan tata cara pelaksanaan PILKADES diperoleh hasil evaluasi sebagai berikut:

TABEL II

HASIL EVALUASI SIKLUS I

\begin{tabular}{|l|l|c|c|l|}
\hline No. & \multicolumn{1}{|c|}{ Nama } & Nilai & KKM & Keterangan \\
\hline 1 & ROHKANI & 80 & 65 & Tuntas \\
\hline 2 & BUDIMAN & 61 & 65 & Tidak Tuntas \\
\hline 3 & SITI SUWARNI & 63 & 65 & Tidak Tuntas \\
\hline 4 & JOKO RAHARJO & 63 & 65 & Tidak Tuntas \\
\hline 5 & ALDO FIRMANTO & 64 & 65 & Tidak Tuntas \\
\hline 6 & ENDANG SAYEKTI & 79 & 65 & Tuntas \\
\hline 7 & CICIH KURNIASIH & 77 & 65 & Tuntas \\
\hline 8 & EDI WIYONO & 81 & 65 & Tuntas \\
\hline 9 & JOKO SANTOSO & 85 & 65 & Tuntas \\
\hline 10 & RINI PALUPI & 81 & 65 & Tuntas \\
\hline 11 & BAMBANG NUGROHO & 61 & 65 & Tidak Tuntas \\
\hline 12 & LINDAWATI & 76 & 65 & Tuntas \\
\hline 13 & FEBIA NURHAYATI & 83 & 65 & Tuntas \\
\hline 14 & FAREL YULIANTO & 80 & 65 & Tuntas \\
\hline 15 & OKTA NIRWANDA & 80 & 65 & Tuntas \\
\hline
\end{tabular}


CIVICS EDUCATION AND SOCIAL SCIENSE JOURNAL(CESSJ)

Volume 2 Nomor 1 Bulan Juni 2020

\begin{tabular}{|l|l|c|c|l|}
\hline 16 & SARAH YULIANA & 63 & 65 & Tidak Tuntas \\
\hline 17 & DADANG GUNAWAN & 63 & 65 & Tidak Tuntas \\
\hline 18 & VONI ERNITA WATI & 64 & 65 & Tidak Tuntas \\
\hline 19 & GEORGE YUNIANTO & 85 & 65 & Tuntas \\
\hline 20 & YENI BONDOWATI & 71 & 65 & Tuntas \\
\hline 21 & JAJANG SETYAWAN & 73 & 65 & Tuntas \\
\hline 22 & NINA KURNIAWATI & 83 & 65 & Tuntas \\
\hline 23 & WAWAN JUTAWAN & 62 & 65 & Tidak Tuntas \\
\hline 24 & JONI INDRIAS & 83 & 65 & Tuntas \\
\hline 25 & TUTIK LESTARI & 68 & 65 & Tuntas \\
\hline 26 & DEDI FIRMANSYAH & 81 & 65 & Tuntas \\
\hline & Jumlah & 1910 & & \\
\hline & Rata-rata & 73,46 & & \\
\hline & Ketuntasan & $65,38 \%$ & & \\
\hline
\end{tabular}

Berdasarkan hasil tes kepada siswa Kelas VI SD Negeri 03 Pacangan Kecamatan Kartasura, Kabupaten Sukoharjo tahun Pelajaran 2019-2020pada siklus I menunjukkan bahwa dari 26 siswa diperoleh nilai rata-rata kelas yaitu 73,46 dengan persentase ketuntasan sebesar $65,38 \%$.

Dalam pelaksanaan pembelajaran siklus I ini kondisi siswa dalam mengikuti kegiatan pembelajaran simulasi sudah dapat berjalan dengan baik, hal tersebut terlihat dari antusias dan kektifan siswa dalam memperagakan simulasi mengenai proses pelaksanaan PILKADES . Hal tersebut disebabkan karena peneliti atau guru sebelum memulai pembelajaran terlebih dahulu melakukan apersepsi dengan menyanyi bersama lagu "Indonesia Raya" sehingga siswa sebelum memulai pembelajaran merasa senang dan termotivasi dalam mengkuti kegiatan pembelajaran dengan menggunakan metode simulasi.

Di samping itu guru dalam melaksanakan kegiatan sumulasi selalu memandu jalannya kegiatan, sehingga siswa merasa diperhatikan dan jalannya pembelajaran simulasi sesuai dengan tujuan yang telah ditetapkan dalam pembelajaran yaitu siswa dapat memperagakan kegiatan simulasi mengenai proses pelaksanaan PILKADES . 
CIVICS EDUCATION AND SOCIAL SCIENSE JOURNAL(CESSJ)

Volume 2 Nomor 1 Bulan Juni 2020

\section{Hasil dan Pembahasan Siklus II}

Berdasarkan hasil evaluasi pembelajaran siklus II pelajaran PKn pokok bahasan proses pelaksanaan PILKADES diperoleh hasil evaluasi sebagai berikut:

TABEL III

HASIL EVALUASI SIKLUS II

\begin{tabular}{|c|c|c|c|c|}
\hline No. & Nama & Nilai & KKM & Keterangan \\
\hline 1 & ROHKANI & 85 & 65 & Tuntas \\
\hline 2 & BUDIMAN & 68 & 65 & Tuntas \\
\hline 3 & SITI SUWARNI & 76 & 65 & Tuntas \\
\hline 4 & JOKO RAHARJO & 85 & 65 & Tuntas \\
\hline 5 & ALDO FIRMANTO & 73 & 65 & Tuntas \\
\hline 6 & ENDANG SAYEKTI & 84 & 65 & Tuntas \\
\hline 7 & CICIH KURNIASIH & 73 & 65 & Tuntas \\
\hline 8 & EDI WIYONO & 80 & 65 & Tuntas \\
\hline 9 & JOKO SANTOSO & 72 & 65 & Tuntas \\
\hline 10 & RINI PALUPI & 72 & 65 & Tuntas \\
\hline 11 & BAMBANG NUGROHO & 65 & 65 & Tuntas \\
\hline 12 & LINDAWATI & 75 & 65 & Tuntas \\
\hline 13 & FEBIA NURHAYATI & 85 & 65 & Tuntas \\
\hline 14 & FAREL YULIANTO & 76 & 65 & Tuntas \\
\hline 15 & OKTA NIRWANDA & 72 & 65 & Tuntas \\
\hline 16 & SARAH YULIANA & 74 & 65 & Tuntas \\
\hline 17 & DADANG GUNAWAN & 65 & 65 & Tuntas \\
\hline 18 & VONI ERNITA WATI & 68 & 65 & Tuntas \\
\hline 19 & GEORGE YUNIANTO & 81 & 65 & Tuntas \\
\hline 20 & YENI BONDOWATI & 83 & 65 & Tuntas \\
\hline 21 & JAJANG SETYAWAN & 72 & 65 & Tuntas \\
\hline 22 & NINA KURNIAWATI & 85 & 65 & Tuntas \\
\hline 23 & WAWAN JUTAWAN & 82 & 65 & Tuntas \\
\hline 24 & JONI INDRIAS & 85 & 65 & Tuntas \\
\hline
\end{tabular}


CIVICS EDUCATION AND SOCIAL SCIENSE JOURNAL(CESSJ)

Volume 2 Nomor 1 Bulan Juni 2020

\begin{tabular}{|c|l|c|c|l|}
\hline 25 & TUTIK LESTARI & 85 & 65 & Tuntas \\
\hline 26 & DEDI FIRMANSYAH & 80 & 65 & Tuntas \\
\hline & Jumlah & 2001 & & \\
\hline & Rata-rata & 76,96 & & \\
\hline & Ketuntasan & $100 \%$ & & \\
\hline
\end{tabular}

Berdasarkan hasil tes kepada siswa kelas VI SD Negeri 03 Pacangan Kecamatan Kartasura, Kabupaten Sukoharjo tahun Pelajaran 20192020pada siklus II menunjukkan bahwa dari 26 siswa diperoleh nilai ratarata kelas yaitu 76,96 dengan persentase ketuntasan sebesar 100\%.

Dalam pelaksanaan pembelajaran siklus II ini kondisi siswa dalam mengikuti kegiatan pembelajaran simulasi sudah dapat berjalan dengan baik, hal tersebut terlihat dari antusias dan kektifan siswa dalam memperagakan simulasi mengenai proses PILKADES. Hal tersebut disebabkan karena peneliti atau guru sebelum memulai pembelajaran terlebih dahulu melakukan apersepsi dengan menyanyi bersama lagu "PILKADES " sehingga siswa sebelum memulai pembelajaran merasa senang dan termotivasi dalam mengkuti kegiatan pembelajaran dengan menggunakan metode simulasi.

Peranan guru dalam pelaksanaan pembelajaran siklus II ini adalah memandu jalannya kegiatan simulasi, jadi setiap kelompok dapat memperagakan kegiatan simulasi sesuai dengan petunjuk yang diberikan oleh guru.

\section{Hasil dan Pembahasan antar Siklus}

Berdasarkan hasil evaluasi pembelajaran PKn pokok proses pelaksanaan PILKADES pada siswa Kelas VI SD Negeri 03 Pacangan Kecamatan Kartasura, Kabupaten Sukoharjo tahun Pelajaran 20192020sebelum dan setelah pelaksanaan pembelajaran dengan menggunakan metode pembelajaran simulasi dapat dilihat dalam tabel V sebagai berikut: 
CIVICS EDUCATION AND SOCIAL SCIENSE JOURNAL(CESSJ)

Volume 2 Nomor 1 Bulan Juni 2020

TABEL V

HASIL EVALUASI ANTAR SIKLUS

\begin{tabular}{|c|l|c|c|l|}
\hline No. & \multicolumn{1}{|c|}{ Nama } & Kondisi Awal & Siklus I & Siklus II \\
\hline 1 & ROHKANI & 78 & 80 & 85 \\
\hline 2 & BUDIMAN & 53 & 61 & 68 \\
\hline 3 & SITI SUWARNI & 63 & 63 & 76 \\
\hline 4 & JOKO RAHARJO & 63 & 63 & 85 \\
\hline 5 & ALDO FIRMANTO & 55 & 64 & 73 \\
\hline 6 & ENDANG SAYEKTI & 68 & 79 & 84 \\
\hline 7 & CICIH KURNIASIH & 60 & 77 & 73 \\
\hline 8 & EDI WIYONO & 74 & 81 & 80 \\
\hline 9 & JOKO SANTOSO & 63 & 85 & 72 \\
\hline 10 & RINI PALUPI & 62 & 81 & 72 \\
\hline 11 & BAMBANG NUGROHO & 45 & 61 & 65 \\
\hline 12 & LINDAWATI & 78 & 76 & 75 \\
\hline 13 & FEBIA NURHAYATI & 84 & 83 & 85 \\
\hline 14 & FAREL YULIANTO & 42 & 80 & 76 \\
\hline 15 & OKTA NIRWANDA & 63 & 80 & 72 \\
\hline 16 & SARAH YULIANA & 60 & 63 & 74 \\
\hline 17 & DADANG GUNAWAN & 47 & 63 & 65 \\
\hline 18 & VONI ERNITA WATI & 57 & 64 & 68 \\
\hline 19 & GEORGE YUNIANTO & 67 & 85 & 81 \\
\hline 20 & YENI BONDOWATI & 57 & 71 & 83 \\
\hline 21 & JAJANG SETYAWAN & 58 & 73 & 72 \\
\hline 22 & NINA KURNIAWATI & 62 & 83 & 85 \\
\hline 23 & WAWAN JUTAWAN & 50 & 62 & 82 \\
\hline 24 & JONI INDRIAS & 67 & 83 & 85 \\
\hline 25 & TUTIK LESTARI & 64 & 68 & 85 \\
\hline 26 & DEDI FIRMANSYAH & 61 & 81 & 80 \\
\hline & Jumlah & 1601 & 1910 & 2001 \\
\hline & Rata-rata & Ketuntasan & 73,46 & 76,96 \\
\hline & & & $100 \%$ \\
\hline
\end{tabular}


CIVICS EDUCATION AND SOCIAL SCIENSE JOURNAL(CESSJ)

Volume 2 Nomor 1 Bulan Juni 2020

Berdasarkan hasil evaluasi pembelajaran dari kondisi awal sampai dengan siklus II menunjukkan bahwa nilai ketuntasan siswa Kelas VI SD Negeri 03 Pacangan Kecamatan Kartasura, Kabupaten Sukoharjo tahun Pelajaran 2019-2020mengalami peningkatan, yaitu pada kondisi awal tingkat ketuntasan $26,92 \%$ dengan nilai rata-rata 61,58, pada siklus I tingkat ketuntasan $65,38 \%$ dengan nilai rata-rata 73,46 , pada siklus II tingkat ketuntasan $100 \%$ dengan nilai rata-rata 76,96.

Untuk lebih jelasnya berikut peneliti sampaikan rekapitulasi tingkat ketuntasan siswa Kelas VI SD Negeri 03 Pacangan Kecamatan Kartasura, Kabupaten Sukoharjo tahun Pelajaran 2019-2020dalam bentuk grafik sebagai berikut:

Berdasarkan hasil evaluasi pembelajaran tersebut, peneliti menyimpulkan bahwa pembelajaran dengan menggunakan metode pembelajaran simulasi dapat meningkatkan prestasi belajar PKn pokok bahasan proses pelaksanaan PILKADES pada siswa Kelas VI SD 03 Pucangan Kecamatan kartasura kabupaten Sukoharjo tahun Pelajaran 20192020.

\section{KESIMPULAN}

Berdasarkan hasil penelitian menganai upaya meningkatkan prestasi belajar PKn melalui metode simulasi pada siswa Kelas VI SD Negeri 03 Pacangan Kecamatan Kartasura, Kabupaten Sukoharjo tahun Pelajaran 20192020pada kondisi awal yaitu dari 26 siswa, sebanyak 7 siswa (26,92\%) dinyatakan tuntas dan 19 siswa $(73,08)$ dinyatakan tidak tuntas dengan nilai rata-rata kelas yaitu 61,58 , pada evaluasi pembelajaran siklus I siswa yang dinyatakan tuntas sebanyak 17 siswa $(65,38 \%)$ dan siswa yang tidak tuntas sebanyak 9 siswa $(34,62 \%)$ dengan nilai rata-rata kelas yaitu 73,46, pada evaluasi pembelajaran siklus II semua siswa dinyatakan tuntas (100\%) dengan nilai rata-rata kelas yaitu 76,96.

Berdasarkan hasil evaluasi pembelajaran tersebut, penulis menyimpulkan bahwa pembelajaran dengan menggunakan metode pembelajaran simulasi dapat meningkatkan prestasi belajar PKn pokok bahasan proses pelaksanaan PILKADES pada siswa Kelas VI SD 03 Pucangan Kecamatan kartasura kabupaten Sukoharjo tahun Pelajaran 2019-2020. 
CIVICS EDUCATION AND SOCIAL SCIENSE JOURNAL(CESSJ)

Volume 2 Nomor 1 Bulan Juni 2020

\section{DAFTAR PUSTAKA}

Ali Fais, 2000, Teori-Teori Belajar, Jakarta : Penerbit Erlangga.

Depdiknas, 2005, Undang-Undang RI No. 20, Sistem Pendidikan Nasional, Semarang: Aneka Ilmu.

Dwi Santoso, 1994, Psycologi Pendidikan, Penerbit Angkasa, Bandung.

ET Ruseffendi, 2002, Pengantar Kepada Membantu Guru Mengembangkan Kompetensinya dalam Pengajaran Matematika Untuk Meningkatkan $C B S A$. Bandung: FPMIPA IKIP Bandung..

Herman Hudoyo, 2004, Strategi Belajar Mengajar Matematika. IKIP Malang: Malang.

Katini Kartono, 2005, Kamus Lengkap Psikologi. Jakarta : P.T. Raja Grafindo Persada.

Ngalim Purwanto, 2002, Ilmu Pendidikan Teoritis Dan Praktis, Bandung: Remaja Rasdakarya.

Omar Hamalik, 2002, Perencanaan Pengajaran Berdasarkan Pendekatan Sistem, Jakarta: P.T Bumi Aksara.

Sardiman, A.M., 2002, Interaksi dan Motivasi Belajar Mengajar, Cet V. Jakarta: Raja Grafindo Persada.

Slameto, 2005, Belajar dan Faktor-faktor Yang Mempengaruhinya, Jakarta: Rineka Cipta.

S. Nasution, 2004, Interaksi dan Motivasi Belajar Mengajar, Jakarta : PT Raja Grafindo Persada.

Sudarmanto, 2003, Media Pendidikan; Pengertian, Pengembangan dan Pemanfaatannya. Jakarta : Raja Grafindo Persada.

Suharsimi Arikunto, 1998, Prosedur Penelitian Suatu Pendekatan Praktek, Jakarta : Rineka Cipta. 
CIVICS EDUCATION AND SOCIAL SCIENSE JOURNAL(CESSJ)

Volume 2 Nomor 1 Bulan Juni 2020

Syah Muhibbin, 1999, Psikologi Belajar, Jakarta: Logos Wacana Ilmu.

The Liang Gie, 2001, Pengantar Filsafat Ilmu, Yogyakarta: Liberty.

Wina Sanjaya, 2006, Strategi Pembelajaran Berorientasi Standar Proses Pendidikan, Jakarta: Kencana Prenada.

Winkel W.S., 2000, Psikologi Pengajaran, Yogyakarta: Media Abadi.

Winarno Surachman, 2004, Dasar-Dasar Bimbingan Dan Penyuluhan, Jakarta: Rineka Cipta. 